\title{
Evaluation of Additional Anomalies in Concomitance of Hypospadias and Undescended Testes
}

\section{Hipospadias ve İnmemiş Testis Birlikteliğinde Ek Anomali Sıklığının Değerlendirilmesi}

\author{
Ufuk ATES, Gülnur GÖLLÜ, Nil YAŞAM TAŞTEKIN, Anar QURBANOV, Günay EKBERLi, \\ Meltem BINGÖL KOLOĞLU, Emin AYDIN YAĞMURLU, Tanju AKTUĞ, Hüseyin DINDAR, \\ Ahmet Murat ÇAKMAK
}

Ankara University Medical School, Pediatric Surgery Department, Pediatric Urology Division, Ankara, Turkey

\begin{abstract}
Objective: Hypospadias is a common genitourinary system (GUS) anomaly in boys occurring in 1 of 200 to 300 live births. Undescended testes is frequently detected among accompanying anomalies in cases with hypospadias. Especially in proximal hypospadias and bilateral cases, this association may indicate sexual differentiation disorders. The aim of the study was to evaluate the togetherness of additional anomalies in hypospadiac children with undescended testes.
\end{abstract}

Material and Methods: Between 2007 and 2016, data of 392 children who underwent surgery for hypospadias were evaluated retrospectively. Urethral meatus was present at scrotal and penoscrotal in 65 cases (16.6\%) and glanular, coronal, subcoronal and midpenile in 327 cases (83.4\%). The cases were divided into two groups as those with both testes in the scrotum and those with undescended testes, and the anomalies were recorded.

Results: The mean age of the children with proximal hypospadias was 21 months (6-240 months). Of the children with proximal hypospadias, $26(40 \%)$ had undescended testes and $39(60 \%)$ had testes in the scrotum. Undescended testes were detected bilaterally in 17 patients $(65.4 \%)$ and unilaterally in nine patients (34.6\%) in the undescended testes group. In the undescended testes group, 24 patients (92.3\%) had suspected external genitalia (bifid scrotum, penoscrotal transposition, togetherness of micropenis and penoscrotal hypospadias, scrotalized labium majus) on physical examination. In the undescended testes group, three patients (11.5\%) had additional urinary pathology and ten patients (38.5\%) had other system anomalies. Ten patients (25.5\%) had suspicious external genitalia on physical examination in the proximal hypospadias group who had both testes in scrotum. Additional urinary pathology was detected in one patient (2.5\%) while other system anomalies were detected in five (12.8\%) patients.

The mean age of children with distal hypospadias was 33 months (6-156 months). Nine of 327 children with distal hypospadias (2.8\%) had undescended testes. Of these, five were bilateral (55.6\%) and 4 had unilateral undescended testes (44.4\%). None of the patients with distal hypospadias had any suspicious genitalia on physical examination. In the undescended testes group, one patient (11.1\%) had additional urinary pathology and one patient had other system anomaly. Seven patients (2.2\%) who had both testes in scrotum had additional urinary pathology and 32 patients (9.8\%) had other system anomalies.

Conclusion: According to our results, further tests such as genitourinary ultrasonography, pelvic MRI if necessary, endocrine and genetic evaluation should be considered in cases where the proximal hypospadias is accompanied by an undescended testicle, and detailed anamnesis and physical examination covering all systems is necessary in all hypospadiac children in terms of additional anomalies.

Key Words: Additional anomalies, Hypospadias, Undescended testes

öz

Amaç: Hipospadias erkek çocuklarda 200-300 canlı doğumda bir görülen genitoüriner sistem (GÜS) anomalisidir. Hipospadias olgularına eșlik eden anomaliler arasında inmemiş testis saptanması sıktır. Özellikle proksimal hipospadias ve bilateral inmemiş testis birlikteliği cinsel farkllașma bozukluklarına işaret edebilir. Bu çalışmada inmemiş testisin eșlik ettiği hipospadiaslı çocuklarda ek anomalilerin değerlendirilmesi amaçlandı. 
Gereç ve Yöntemler: 2007-2016 yılları arasında hipospadias nedeniyle ameliyat olan 392 çocuğun verileri geriye dönük olarak tarandı. Bunlardan 65 (\%16.6) olguda meatus skrotal ve penoskrotal, 327'sinde (\%83.4) glanüler, koronal, subkoronal ve midpenil yerleșimliydi. Olgular her iki testisi yerinde olan ve olmayanlar olarak ayrıldı ve ek anomaliler kaydedildi.

Bulgular: Proksimal hipospadiası çocukların ortanca yașı 21 ay (6-240 ay)'dı. Proksimal hipospadiası çocuklardan 26'sının (\%40) inmemiș testisi mevcutken, 39 (\%60) olguda testisler skrotumda ele geldi. İnmemiș testisi olan gruptaki hastaların 17'sinde bilateral (\%65.4), dokuzunda tek taraflı (\%34.6) inmemiş testis saptandı. Inmemiş testisi olan grupta 24 hastada (\%92.3) fizik muayenede kuşkulu dış genitalya (bifid skrotum, penoskrotal transpoziyon, mikropenis ve penoskrotal hipospadias beraberliği, skrotalize labium majus) mevcuttu. Inmemiş testisi olan grupta üç hastada (\%11.5) ek üriner anomali, on hastada (\%38.5) ise diğer sistem anomalilerinin eșlik ettiği saptandı. Her iki testisin ele geldiği proksimal hipospadias hasta grubunda 10 hastada ( \%25.5) kușkulu diş genitalya mevcuttu. Her iki testisi skrotumda ele gelen 39 hastanın birinde (\%2.5) ek üriner patoloji, beșinde (\%12.8) ise diğer sistem anomalilerine rastlandı.

Distal hipospadiaslı çocukların ortanca yașı 33 ay (6-156 ay)'dı. Distal hipospadiaslı 327 çocuğun 9'unda (\%2.8) inmemiş testis mevcuttu. Bunlardan beșinde bilateral (\%55.6), 4'ünde tek taraflı (\%44.4) inmemiş testis izlendi. Distal hipospadiası olan hastaların hiç birinde (\%0) fizik muayenede kuşkulu genitalya saptanmadı. Inmemiş testisi olan grupta bir hastada (\%11.1) ek üriner patoloji, bir hastada (\%11.1) ise diğer sistem anomalilerinin eşlik ettiği saptandı. Her iki testisi skrotumda ele gelen yedi hastada (\%2.2) ek üriner patoloji, 32 hastada (\%9.8) ise diğer sistem anomalilerine rastlandı.

Sonuç: Sonuçlarımıza dayanarak inmemiş testisin eşlik ettiği proksimal hipospadiasılı olgularda ürogenital sisteme yönelik ultrasonografi, gerektiğinde pelvik MRG, endokrinolojik analiz, genetik inceleme gibi ileri tetkik gerekliliğinin akılda tutulması gerektiği, tüm hipospadiası çocuklarda ek anomaliler açısından tüm sistemleri içeren ayrıntılı anamnez ve fizik muayene ile tetkik edilmesi gerektiği kanısındayız.

Anahtar Sözcükler: Ek anomali, Hipospadias, Inmemiş testis

\section{INTRODUCTION}

Hypospadias is a common genitourinary system (GUS) anomaly in boys occurring in 1 of 200 to 300 live births (1). Undescended testes is frequently detected among accompanying anomalies in cases with hypospadias. Especially in proximal hypospadias and bilateral cases, this association may indicate sexual differentiation disorders. The aim of the study was to evaluate the incidence of togetherness of hypospadias with undescended testes and additional anomalies.

\section{PATIENTS and METHODS}

Data of 392 children who underwent surgery for hypospadias between 2007 and 2016 were screened retrospectively. The urethral meatus was scrotal and penoscrotal in 65 cases (16.6\%) and glanular, coronal, subcoronal and midpenile in 327 cases (83.4\%). The cases were divided into two groups as those with both testes in the scrotum and those with undescended testes, and the anomalies are recorded.

\section{RESULTS}

The overall incidence of undescended testes in all hypospadias cases found to be $8.9 \%$. The mean age of the children with proximal hypospadias was 21 months (6-240 months). Of the children with proximal hypospadias, $26(40 \%)$ had undescended testes and $39(60 \%)$ had testes in the scrotum. Undescended testes were detected bilaterally in 17 patients (65.4\%) and unilaterally in nine patients (34.6\%). In the undescended testes plus proximal hypospadias group, 24 patients (92.3\%) had suspected external genitalia on physical examination (Table I).
Sixteen of these patients had bilateral and eight had unilateral undescended testes. Fourteen of these patients (53.8\%) had associated genetic and endocrinological disease (5-alpha reductase deficiency $(n=4)$, partial androgen receptor insensitivity $(n=4)$, congenital adrenal hyperplasia $(n=3)$, gonadal dysgenesis $(n=2)$, Klinefelter syndrome $(n=1))$. Of the 14 patient which had associated genetic and endocrinological disease 7 had proximal hypospadias associated with bilateral undescended testes and other 7 patient had proximal hypospadias associated with unilateral undescended testes. In the undescended testes group, three patients (11.5\%) had additional urinary pathology and ten patients $(38.5 \%)$ had other system anomalies (Table II). Ten patients (25.5\%) had suspicious external genitalia on physical examination in the proximal hypospadias group who had both testes in scrotum (Table I). Four of them (10.3\%) had associated genetic and endocrine disease (partial androgen receptor insensitivity $(n=3)$, congenital adrenal hyperplasia $(n=1))$. Additional urinary pathology in one patient $(2.5 \%)$ and other system anomalies in five (12.8\%) patients were detected in 39 patients who had both testes in the scrotum (Table II).

The mean age of children with distal hypospadias was 33 months (6-156 months). Nine of 327 children with distal hypospadias $(2.8 \%)$ had undescended testes. Of these, five were bilateral (55.6\%) and 4 had unilateral undescended testes (44.4\%). None of the patients with distal hypospadias had any suspicious genitalia on physical examination and these cases had no associated genetic or endocrine diseases. In the undescended testes group, one patient (11.1\%) had additional urinary pathology (left horseshoe kidney $(n=1))$ and one patient had other system anomalies (Down syndrome $(n=1)$ ) (Table I). Seven patients (2.2\%) who had both testes in the scrotum had additional urinary pathology (left multicystic dysplastic kidney $(n=2)$, antenatal hydronephrosis $(n=2)$, right vesicoureteral 
reflux $(n=1)$, kidney stone $(n=1)$ left Wilms tumor $(n=1))$, and 32 patients $(9.8 \%)$ had other system anomalies including inguinal hernia( $n=9)$, neurological $(n=5)$, allergic-immunologic $(n=5)$, cardiac $(n=4)$, hypothyroidism $(n=2)$, anal atresia $(n=2)$, skeletal anomalies $(n=2)$, Hirschsprung's disease $(n=1)$, hemophilia $(n=1)$ and familial Mediterranean fever $(n=1)$ (Table I).

\section{DISCUSSION}

Because of the common etiological factors such as endocrine disruption, genetic disorders, placental insufficiency and familial clustering concomitance of other system anomalies in distal hypospadias, this patient group should not be neglected. According to the present study, a systemic overview of hypospadiac children is mandatory.

Hypospadias is a developmental anomaly characterized by an urethral meatus that opens to the ventral surface of the penis. The meatus may be located anywhere along the penis from the glans to the perineum. Distal hypospadias generally appears as an isolated anomaly. Twenty percent of the hypospadias cases are classified as proximal hypospadias. The main cause of hypospadias is thought to be a defect in the androgen stimulation of the developing penis. Androgens also play an important role in the descent of the testes. The frequency of undescended testes is increased in boys with diseases that affect androgen secretion or function (1). Disorders of sexual development (DSD), and urological and nonurological anomalies seem to have higher incidence in the presence of proximal hypospadias with undescended testes. Undescended testes and hypospadias are the most common malformations of external male genitalia (2). The reported incidence of undescended testes varies between $0.5 \%$ and $9 \%(1-5 \%$ in most reports) (3). The worldwide incidence of hypospadias ranges from 0.6 to 34.2 per 10000 live births (3). Simultaneous occurrence of both anomalies in the same individual has been shown to be present in $4 \%$ to $20 \%$ of cases (4). The incidence of undescended testes accompanying hypospadias in our study was similar to the literature (8.9\%). The exact mechanism of testicular descent is unknown but is generally accepted to be under some degree of hormonal control with androgen mediation. Tubularization of the urethral folds is thought to be under the influence of androgen between 7 to 10 weeks of embryogenesis. Androgen related factors seem to be important in the etiology of both anomalies. The association of disrupted androgen stimulation with incomplete tubularization of the urethra and testicular maldescent has been well demonstrated in animal models. This relationship of androgen mediated causes for hypospadias and cryptorchidism has also been linked in humans with disruption of the androgen axis in DSD. Because of the androgen influence on etiology of both these anomalies, a patient with bilateral or unilateral undescended testes plus hypospadias should be evaluated carefully. The DSD incidence in patients with undescended testes plus hypospadias is reported to be between $27 \%$ and $50 \%(5,6)$. In a study reported by Rafjer and Walsh, the DSD incidence in otherwise normal appearing males with hypospadias plus undescended testes was found to be $27 \%$. A 53\% rate of DSD was found in patients with ambiguous genitalia who had hypospadias plus undescended testes (5). In conclusion, they recommend complete evaluation of all patients with combined hypospadias and undescended testes. DSD cases were found to have a high incidence in the proximal hypospadias and undescended testes group in the present study too. In contrast, we found increased additional anomaly togetherness in isolated distal hypospadias. Mc Aller and Kaplan (7) evaluated the necessity of karyotype analysis in patients with hypospadias and/or chordee plus undescended testes. They argued that routine karyotype investigation of all patients with hypospadias, chordee and cryptorchidism does not seem warranted except in patients with perineal hypospadias and cryptorchidism. Cox et al. (4) reported karyotyping to be evaluated in patients with proximal hypospadias because of the high incidence (32\%) of concomitant anomalies. Kaefer et al. (8) evaluated the incidence of DSD in patients with hypospadias and undescended testes without ambiguous genitalia. The incidence of DSD in patients with bilateral undescended testes and hypospadias was found to be higher. In the present study, in concordance with the literature, the percentage of DSD in proximal hypospadias plus bilateral undescended testes and isolated proximal hypospadias group was 53.8 and 25.5 respectively. No DSD patients were found in distal hypospadias group with unilateral and bilateral undescended testes. Hypospadias is generally an isolated anomaly but it may represent one of the features of over 200 different syndromes and congenital anomalies. There are several studies showing co-occurrence of hypospadias with congenital anomalies (9-11). The literature reports that up to $2.2-10.5 \%$ of patients with anorectal malformations also have hypospadias

Table I: The number of urinary and additional anomalies seen with hypospadias with and without undescended testes.

\begin{tabular}{l|c|c|c}
\hline & N & DSD & $\begin{array}{c}\text { Urinary } \\
\text { Additional } \\
\text { anomalies }\end{array}$ \\
\hline Proximal hypospadias + undescended testes & $26(40 \%)$ & $14(53.8 \%)$ & $3(11.5 \%)$ \\
\hline Isolated proximal hypospadias & $39(60 \%)$ & $4(10.3 \%)$ & $1(2.5 \%)$ \\
\hline Distal hypospadias + undescended testes & $9(2.8 \%)$ & 0 & $1(11.1 \%)$ \\
\hline Isolated distal hypospadias & $318(97.2 \%)$ & 0 & $7(2.2 \%)$ \\
\hline
\end{tabular}


$(12,13)$. Chaijan et al. (14) investigated urogenital abnormalities in children with primary congenital hypothyroidism. The frequency of hypospadias among urogenital abnormalities in patients with congenital hypothyroidism was found to be $40.2 \%$. They advice further evaluation of the urogenital system in children with hypothyroidism at birth. In the present study, a variable percentage of a wide-range of additional anomalies was found among different hypospadias patient groups, similar to the literature. Other system anomalies accompanying hypospadias seemed to increase with the severity of hypospadias in the present study (Table I).

Genital and urinary anomalies associated with hypospadias have been reported together by some authors and not by others. The true incidence of urinary tract anomalies seen with hypospadias varies (10). Urinary tract anomalies seem to be at a rate of $11.5 \%$ in the proximal hypospadias group with undescended testes, 2.5\% in the isolated proximal hypospadias group, \%11.1 in the distal hypospadias with undescended testes group and \%2.2 in the isolated distal hypospadias group. Urinary anomalies found in all groups were antenatal hydronephrosis, horseshoe kidney, multicystic displastic kidney, vesicourethral reflux, nephrolithiasis and Wilms tumor. By concomitance of undescended testes to proximal and distal hypospadias, the percentage of genitourinary anomalies increases to $11.5 \%$ and $11 \%$, while this percentage is $2.5 \%$ and $2.2 \%$ in isolated proximal and distal hypospadias group respectively. Referring to this increase, we recommend further evaluation of the genitourinary system in the existence of undescended testes in proximal and distal hypospadias patients. The existence of congenital anomalies in proximal hypospadias with undescended testes is obviously supported by the literature. Similar to most of the published reports, we found an increased incidence of DSD and other system anomalies in proximal hypospadias patients. No extragenitourinary anomalies were found in distal hypospadias while only one was present in the distal hypospadias plus undescended testes group. Surprisingly, 32 (9.8\%) isolated

Table II: Additional anomalies in hypospadias patients.

\begin{tabular}{|c|c|c|c|c|c|c|c|c|c|c|c|c|c|c|c|c|c|c|c|c|}
\hline & \multicolumn{6}{|c|}{$\begin{array}{c}\text { Genitourinary system } \\
\text { anomalies }\end{array}$} & \multicolumn{14}{|c|}{ Additional anomalies } \\
\hline & I & 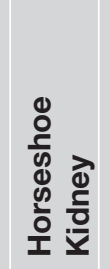 & 产 & $\stackrel{\Re}{\lessgtr}$ & 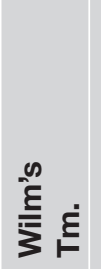 & 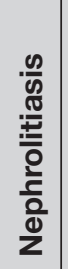 & ஸ் & 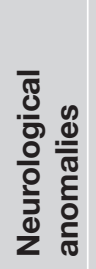 & $\frac{\sqrt{0}}{\frac{0}{9}}$ & 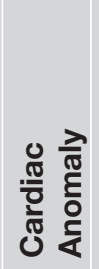 & 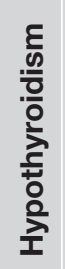 & 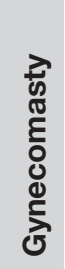 & ڤ $\frac{\overline{0}}{\frac{c}{0}}$ & 흘 & $\begin{array}{l}\frac{\pi}{0} \\
\Phi \\
\frac{0}{0} \\
\frac{0}{\alpha}\end{array}$ & 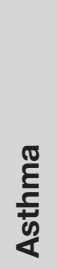 & $\sum_{\amalg}^{\text {L }}$ & 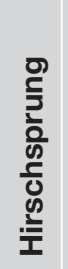 & 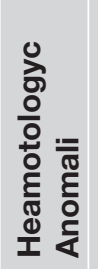 & 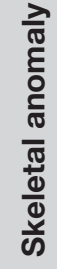 \\
\hline $\begin{array}{l}\text { Proximal } \\
\text { hypospadias+ } \\
\text { bilateral } \\
\text { undescended } \\
\text { testes }\end{array}$ & 1 & & & & & & 1 & 2 & 1 & 3 & 1 & 1 & & & & & & & & \\
\hline $\begin{array}{l}\text { Proximal } \\
\text { hypospadias+ } \\
\text { unilateral } \\
\text { undescended } \\
\text { testes }\end{array}$ & & 1 & 1 & & & & & & & & & & & & & & & & & 1 \\
\hline $\begin{array}{l}\text { Isolated proximal } \\
\text { hypospadias }\end{array}$ & 1 & & & & & & & & & 1 & & & & 2 & 1 & 1 & & & & \\
\hline $\begin{array}{l}\text { Distal } \\
\text { hypospadias+ } \\
\text { bilateral } \\
\text { undescended } \\
\text { testes }\end{array}$ & & 1 & & & & & 1 & & & & & & & & & & & & & \\
\hline $\begin{array}{l}\text { Distal } \\
\text { hypospadias+ } \\
\text { unilateral } \\
\text { undescended } \\
\text { testes }\end{array}$ & & & & & & & & & & & & & & & & & & & & \\
\hline $\begin{array}{l}\text { Isolated distal } \\
\text { hypospadias }\end{array}$ & 2 & & 2 & 1 & 1 & 1 & & 5 & 2 & 4 & 2 & & 5 & 9 & & & 2 & 1 & 1 & 2 \\
\hline
\end{tabular}


distal hypospadias patients had accompying extragenitourinary malformations.

\section{CONCLUSION}

Proximal hypospadias associated with undescended testes is thought to occur as a developmental disorder in the earlier stage of GUS maturation. Beside these, some other developmental disorders may also be encountered with the organogenesis duration encompassing the same period. So it is important to keep in mind the possibility of the presence of one of these anomalies if another anomaly is diagnosed. Sexual differentiation disorders, and comorbid genetic and endocrine disorders that concern the reproductive system are common in these patients compared to other patient groups. According to our results, we suggest that further tests may be needed in cases where the hypospadias is accompanied by undescended testes and an investigation should be conducted in all hypospadiac children in terms of additional anomalies.

\section{REFERENCES}

1. Weidner IS, Moller H, Jensen TK, Skakkebaek NE. Hypospadias in Washington State: Maternal risk factors and prevalence trends. Pediatrics 2005;115:495-9.

2. Scorer $\mathrm{C}$, Farrington $\mathrm{GH}$. Congenital deformities of the testis and epididymis. New York: Appleton-Century Crofts, 1971.

3. Diamond DA, Chan IHY, Holland AJA, Kurtz MP, Nelson C, Estrada CR Jr, et al. Advances in pediatric urology. Lancet 2017;390:106171
4. Cox MJ, Coplen DE, Austin PF. The incidence of disorders of sexual differentiation and chromosomal abnormalities of cryptorchidism and hypospadias stratified by meatal location. J Urol 2008;180:2649-52.

5. Rajfer J, Walsh PC. The incidence of intersexuality in patients with hypospadias and cryptorchidism. J Urol 1976;116:769-70.

6. Rohatgi M, Menon PS, Verma IC, lyengar JK. The presence of intersexuality in patients with advanced hypospadias and undescended gonads. J Urol 1987;137:263-7.

7. McAleer IM, Kaplan GW. Is routine karyotyping necessary in the evaluation of hypospadias and crytporchidism? J Urol 2001;165:2029-31.

8. Kaefer M, Diamond D, Hendren WH, Vemulapalli S, Bauer SB, Peters CA, et al. The incidence of intersexuality in children with cryptorchidism and hypospadias: Stratification based on gonadal palpability and meatal position. J Urol 1999;162:1003-6.

9. Manzoni G, Bracka A, Palminteri E, Marocco G. Hypospadias surgery: When, what and by whom? BJU Int 2004;94:1188-95.

10. Friedman T, Shalom A, Hoshen G, Brodovsky S, Tieder M, Westreich $M$. Detection and incidence of anomalies associated with hypospadias. Pediatr Nephrol 2008;23:1809-16.

11. Corder JP, Al Ahbabi FJS, Al Dhaheri HS, Chedid F. Demographics and co-occurring conditions in a clinic-based cohort with Down syndrome in the United Arab Emirates. Am J Med Genet 2017;173A:2395-407.

12. Brock WA, Pena A. Urological implications of imperforated anus. AUA Update Series 1991;X:202-7.

13. Yucel S, Dravis C, Garcia N, Henkemeyer M, Baker LA. Hypospadias and anorectal malformations by Eph/ephrin signaling. J Pediatr Urol 2007;3:354-63.

14. Chaijan PY, Dorreh F, Sharafkhah M, Amiri M, Ebrahimimonfared M, Rafeie M, et al. Congenital urogenital abnormalities in children with congenital hypothyroidism. Med J Islam Repub Iran 2017;31:7. 